\title{
Contesting the Commercialization and Sanctity of Religious Tourism in
}

\section{The Shaolin Monastery, China}

\section{Abstract}

The Shaolin Monastery annually attracts millions of visitors from around the world. However, the overcommercialization of these sacred places may contradict the values and philosophies of Buddhism. This study aims to comprehensively understand the balance between commercialization and sanctity, engaging with 58 Chinese practitioners and educators in 7 focus groups. Participants articulated their expectation to avoid overcommercialization, and they discussed the conflicts between commercialization and sanctity to further explore on how to mitigate over commercialization. Based on the study findings, a balanced model of religious tourism development is proposed and specific recommendations are offered to sustainably manage religious sites.

Keywords: Shaolin monastery, kung fu, culture, commercialization, sanctity, religion 


\section{INTRODUCTION}

A popular Chinese saying states that “All martial arts under heaven arose out of the Shaolin Monastery.” The Shaolin Monastery is the birthplace of Dhyana (also known as Zen, a Buddhism philosophy that emphasizes internal meditation) and Shaolin kung fu, which evolved from Buddhism. This martial art tradition, which spanned for over 1,500 years, involves the Shaolin monks learning the Buddhism doctrines and practicing the Dhyana (Chan) philosophy in their martial arts. This practice has distinguished Shaolin kung fu from other types of Chinese kung fu (The Shaolin Monastery, 2010). The movie Shaolin Monastery released in 1982 established the global reputation of Chinese kung fu and the Shaolin Monastery. A number of movies are also made subsequently based on topics involving Chinese kung fu and the monastery. For example, the recent movie, The Grand Masters (2013), introduced kung fu worldwide as a fascinating element of the Chinese culture. The Shaolin Monastery, a conglomeration of Buddhism and kung fu, is commonly recognized as a representative of Chinese culture. Thus, this monastery has attracted millions of visitors from around the world every year (Shahar, 2008).

Kung fu and Buddhism have intensified the commercialization of the Shaolin Monastery. Located in Dengfeng, Henan Province in China, the Shaolin Monastery has a history spanning over 1,500 years (Shaolin Monastery, 2010) and displaying ancient Buddhist architecture and cultural artifacts. The monastery has become the most popular tourist attraction among kung fu enthusiasts, who appreciate and study Shaolin kung fu. However, the active involvement of the Shaolin Monastery in commercial activities such as tourism development has generated several concerns on the long-term practice of its core values, such as Buddhism, meditation, and spirituality (Beijing Review, 2006). The multitude of tourists who visit the Shaolin Monastery annually and the rapid development of 
the local tourism industry (e.g., hotels, restaurants, and entertainment attractions) have induced the overcommercialization of this religious heritage site (Olsen, 2003).

Given the global popularity of the Shaolin Monastery, developing the temple as a tourist destination can be a profitable business. The monastery is located in Henan Province, where numerous political movements occurred in ancient China. Thus, the Shaolin Monastery is normally associated with the national pride of the Chinese and is vividly presented in several popular Chinese fiction and movies. Although the historical and architectural values of the Shaolin Monastery are clearly reflected in its world heritage recognition, the development of the temple requires further attention to pursue a balance among the different interests. However, the commercialization of sacred places, particularly the Shaolin tourism business, may contradict the values and philosophies of Buddhism. As such, the core values of Buddhism may be compromised over time if Shaolin tourism is not sustainably managed. The case of the Shaolin Monastery is not solitary because finding a balance between preservation and development is a major management challenge for religious sites regardless of religion. However, Olsen (2006) noted the limited academic attention on the complex management issues in religious sites. Therefore, this study aims to explore the multiple meanings of the Shaolin Monastery as a carrier of Buddhism and Chinese culture in terms of tourism development. Stake (2005) suggested that an in-depth exploration of one typical example can support and enhance the understanding of the general phenomena. Thus, the present study also intends to broaden the understanding of the dilemma between commercialization and sanctity in the context of the Shaolin monastery, which is a conglomeration of kung fu, Buddhism, and tourism. The findings derived from this representative case, which accommodated an overwhelming number of tourists, can generate important implications for the sustainable development of other religious sites; the 
results from this case study will also have implications on other culturally-sensitive sites that experience a high number of visitations with similar management struggles.

\section{Quest for sanctity in religious tourism}

Sanctity is central to the maintenance of the religious sense or authenticity of a place (Olsen, 2006), and it is commonly used interchangeably with authenticity in religious tourism. Both sanctity and authenticity are are regarded as the counterpart of commercialization of religious sites. Shackley (2002) applied the concept of sanctity in a study of 43 cathedrals and pointed out some elements in creating sanctity, such as “a closeness to God” and "the gaining of spiritual merit” (p. 345). From a managerial perspective, Olsen (2006) identified several managerial suggestions to maintain sanctity, such as distancing from commercialization, restricting some areas from visitors, introducing religious knowledge by specialized guides, and controlling overcrowding. Charging entrance fees can damage the sanctity of believers who have to "pay to pray" (Shackley, 2002). The physical effects of overcrowding destroy reverent and peaceful atmospheres (Olsen, 2006). Notably, sanctity, as part of an authentic religious experience, appeals to both "sacred” and "secular" visitors.

The quest for sanctity in a religious site journey has been widely acknowledged in religious tourism studies. Religious tourism has been traditionally defined as "a form of tourism where people of a particular faith travel to visit places of religious significance in their faith” (El Hanandeh, 2013, p. 1). Thus, religious sites are socially constructed as sacred; however, for non-believers, these sites do not necessarily embody intrinsic holiness (Belhassen, Caton, \& Steward, 2008; Bremer, 2006).

Four common distinctions in the types of religious sites, namely, pilgrimage shrines, religious structures, festivals, and purpose- 
built attractions are identified in the literature (Nolan \& Nolan, 1992; Shackley, 2003; Shoval, 2000). Whereas pilgrimage shrines primarily serve spiritual journeys, religious structures are common places of worship and festivals are often religious gatherings. Pilgrimage shrines are also considered inherently sacred (Olsen, 2003); however, purpose-built religious attractions are designed to draw visitors for tourism.

Consequently, a common dichotomy of religious attraction has emerged based on visitors' travel motivations, namely, pilgrims and tourists (Hughes, Bond, \& Ballantyne, 2013). Pilgrimage, commonly defined as wandering toward sacred sites as an act of will or religious obligation, has been at the core of religious tourism since ancient times (Josan, 2009). In recent times, this phenomenon has experienced a global revival and an increased interest as a form of tourism (Collins-Kreiner, Kliot, Mansfeld, \& Sagi, 2006); however, this phenomenon lacks related empirical studies (Collins-Kreiner \& Kliot, 2000). Pilgrims are commonly labeled as “believers” who celebrate their faith (Ambrósio, 2007) and search for meaning and authenticity (Cohen, 1979). In contrast, traditional tourists visit religious heritage sites for other purposes, such as those related to nature, culture, history, beauty, leisure, adventure, and amusement (Bremer, 2006; Shackley, 2005). Cohen (1992) stated that visitors who adhere to a religion relevant to the site can be labeled as pilgrim-tourists, whereas non-believers are considered traveler-tourists.

Smith (1992) developed a related continuum model in which pilgrims and tourists are at the opposite sides labeled "sacred” and “secular,” respectively. An almost infinite number of combinations are assumed between these two extremes, representing the visitors’ often-changing travel motivations to religious sites (Hughes et al., 2013). Most religious tourism are believed to fall in the middle of this continuum, in which tourists are neither firm believers nor totally secular (Collins-Kreiner \& Gatrell, 2006; Collins-Kreiner, 
2010). Olsen (2013) added that only a few tourists claim to be pilgrims, whereas most expect certain types of emotional experience upon their visit.

Recent studies have failed to distinguish pilgrimage from traditional tourism. Nelson Grauburn (1983, p. 16) stated that "there is no hard and fast dividing line between pilgrimage and tourism, that even when the roles of pilgrim and tourist are combined, they are necessarily different but form a continuum of inseparable elements.” Subsequently, a pilgrim can be defined by the collective experience and the common identity (Peelen \& Jansen, 2007). Furthermore, Cazaux (2011) argued that the pilgrim experience can be shared even without the sense of belonging to any established religion. He defined pilgrims based on their participation in a certain activity, the feeling of being part of a group, and the recognition as pilgrims by both group members and non-members.

Following this line of thought, Digance (2003; 2006) introduced the concept of “new” pilgrims, who are both modern and secular in character. This new form of tourism borrows from the New Age movement in following a personal spiritual path outside the mass pilgrimage tradition and organized religious tendencies (Digance, 2003; Reader, 2007). Jirásek (2011) indicated that secular tourism can be transformed into spiritual tourism if a traveler perceives the former as an authentic journey. Scholars have identified a wide range of secular travel motivations to religious heritage sites that are often combined with spiritual needs. These motivations include “cultural and historical interest” (Shackley, 2005, p. 34), architectural interest, spur-of-the moment decisions, and group travel, as well as visits to graves or ancestral monuments and famous people connected with the site (Hughes et al., 2013; Rinschede, 1992). Andriotis (2009) added that the pilgrimage experience today includes elements of culture, secularity, nature, education, and even religious devotion. Several studies have indicated that worshippers are often part of the minority of religious site visitors (Jackson \& 
Hudmann, 1995; Smith, 1992; Winter \& Gasson, 1996; Vukonic, 1996). Di Giovine (2011) explained that although the interpretations of sacred sites are often negotiated among different types of visitors, they often establish communication bonds showing their collective appreciation of the sites. From a supply perspective, sacred sites welcome visitors for several reasons that are not always necessarily related to faith. The common alternative motivations to hospitality include displaying buildings, generating cash, or enhancing a sense of community (Shackley, 2005). From a different perspective, Della Dora (2012) and Lois-González and Santos (2014) stated that in modern times, most people with pilgrimage as their major travel motivation are also tourists when visiting sacred sites. Thus, a spiritual journey can also include traditional secular sightseeing, such as simply enjoying the scenery at a pilgrimage site.

Therefore, the simplified notion that faith merely drives the religious tourism process should be questioned because religious and traditional tourism are interconnected (Ambrósio, 2007; Kaszowski, 2000; Stausberg, 2011). Existing literature also reflects that religious beliefs are not the only reason tourists visit or host open religious sites for tourism, instead, the quest for sacredness is a common motive across all religious site visitors. This situation presents a dilemma on the role of sanctity in commercializing a religious place via tourism.

\section{Commercialization of religious heritage}

Commercialization and commodification are concepts that have mostly emerged through postmodern ideas, such as skeptical views on power relations, nostalgia, and perceived loss of authenticity (Bailey, 2008; Cole, 2007; Goulding, 2000). Commodification is typically defined as tourism that transforms a culture or heritage into a commercialized product, which is packaged and sold to tourists for their consumption (Cole, 2007). Similarly, commercialization involves rendering tourist sites available for profitable 
purposes (Kontogeorgopoulos, Churyen, \& Duangsaeng, 2015). Both concepts are believed to diminish authenticity (Taylor, 2001) and to ultimately reduce the value of a tourism product (Go, 1997; Swain, 1989).

Commercialization critics argued that tourism products have become simply another commercialized commodity, which are bought and sold on the market for financial gain (Hiller, 1976). Britton (1991) elaborated on the two stages of this process which ultimately transforms places into commercialized attractions. In the first stage, non-commercial products such as places are transformed into tourism products. This transformation occurs by naming an attraction and separating it demographically from its surroundings (MacCannell, 1976). In the second stage, non-tourist attractions become tourism products through the acquaintance on the new meanings projected on these attractions. The latter is commonly enforced through marketing, image building, and branding efforts using tools such as music, literature, television broadcasts, and movies (Roesch, 2009).

Nevertheless, several scholars have regarded the commercialization of culture and heritage as merely a destructive, oppressive, and negative concept. In contrast, commercialization is believed to have positive aspects particularly on the local people at the heritage sites (Cole, 2007; Finn, 2009; Xie, 2003). A major benefit of commercialization is its capacity to aid in the survival of folk customs and traditions (Su, 2011). Several related success stories have been narrated, such as the case of Cuban music (Finn, 2009) and the traditional performances in China (Xie, 2003). By showcasing local traditions, the young members of society are introduced to and learn to appreciate such traditions, which ultimately guarantee their future survival.

The commercialization of tourism sites also generated economic opportunities, particularly for local businesses (Mason, 2004). Other scholars have argued that local communities can be empowered through commercialization (Bianchi, 2003; Oakes, 1993). 
Hence, marginalized communities can reaffirm their identity and maintain their sense of autonomy by showcasing their culture to the outside world.

Aside from traditional tourist attractions, commercialization has also affected religious heritage. The latter shares several common features with the former; however, the special context of religion and sanctity of a site requires further consideration when investigating commercialization. Bremer (2001) explained that the borders among different types of religious attractions start to overlap with the heavy touristification of religious heritage sites. Promotion-aimed marketing efforts particularly create confusion between religion and tourism, as well as between heritage and leisure relative to these attractions.

The significant increase of tourism activities in certain sites has also led to leisure-oriented visitors effectively outnumbering the worshippers (Cohen, 1988; Shackley, 2002). Religious items also often lose their original purpose and become souvenirs, which can eventually harm the religious sense of the place (Cohen, 1988). Singh (1997) indicated that tourist-related facilities, such as hotels and other lodging structures, can also seriously damage the religious landscapes and the surroundings of an attraction. Shinde (2007) added that overcrowding and increased consumerism often transform religious tourism into mass tourism because significantly more secular visitors are also attracted to religious tourism sites. In this case, the tourism business itself acts as a direct commercializing agent of religious heritage attractions.

Olsen (2003) identified another type of religious heritage commercialization, which is commercialization through religious groups. In this case, religious groups “sell” their beliefs and customs for economic purposes. Certain attractions related to the Roman Catholic Church, such as the Vatican City, are mentioned as an example (Nolan \& Nolan, 1992). In this case, even religious artifacts 
are sold as souvenirs, thereby defying their original meanings (Olsen, 2003).

Despite the often criticized negative effects, the religious commercialization of tourist attractions is believed to have a positive aspect. In practice, the commercialization of religious sites has proven vital to a substantial number of attractions. Aside from the financial gain of commercialization, the stimulation of certain types of site interpretations may also interest diverse religious groups and authorities to promote their religions (Bandyopadhyay, Morais, \& Chick, 2008; Philp \& Mercer, 1999; Waitt, 2000). This situation can eventually induce friction between two related groups that promote diverse interpretations of the same attraction, as well as among diverse religions that worship the same site for different purposes (Olsen \& Timothy, 2002; Timothy \& Boyd, 2003). Other organizations, such as New Age movements, also commercialize religion by adopting and selling items sacred to others' faith for financial and economic gains (Attix, 2002). Shackley (2005) highlighted that in practice, the revenue from tourist visits in the form of donations, admission fees, catering, or merchandising has frequently proven crucial for the survival of a religious site. Levi and Kocher (2009) explained that although external observers frequently criticize the financial demands of visitors, religious institutions can limit the number of visitors and control the overcrowding of a site. This situation is a direct consequence of religious institutions generally not enjoying the exceptional status they experienced during the last millennia; they have often struggled to overcome financial and management issues (Olsen, 2006; Shackley, 2005), as well as sought new members to join their community (Nolan \& Nolan, 1992).

The awareness of local people as stakeholders in religious tourism attractions is also noted. Levi and Kocher (2009) indicated that both locals and tourists can be considered indispensable to a religious attraction. Accordingly, although tourists guarantee financial 
survival, local community involvement guarantees that the sense of place and the religious traditions are maintained to limit the effects of commercialization.

The commercialization of religious heritage sites can be considered a highly complex issue, which involves several threatening and beneficial aspects of the attraction, as well as the issue of striking a balance between the commercialization and sanctity of a site (Raj \& Morpeth, 2007). Therefore, understanding this issue is important because tourism and pilgrimage as well as commercialization and sanctity are continuously blurring topics in the context of religious heritage.

\section{Shaolin Monastery}

The aforementioned situation is particularly important in the context of China, where commercialization has affected different types of religious heritage because of the rapid influx of tourists (Philp \& Mercer, 1999; Su, 2011; Xu, Yan, \& Zhu, 2013). China’s religious heritage has included conflicts among different religious groups and ethnicities (Kang, 2009). Kang (2009) cited the Huanglong Temple in Sichuan as an example to highlight the struggle for interpretation. Buddhist, Taoist, and Tibetan monks are claiming different temples within the same monastery to present their respective historical and religious hegemonies. All of these groups are determined to use religious tourists as catalysts to highlight and to enhance their respective ethnic, cultural, and spiritual influences. This condition reaffirms Coleman and Eade’s (2004) notion that pilgrimage is a politically charged force related to economic and cultural systems. In the case of the Shaolin Monastery, research is scarce at best, which represents both its contradiction and its popularity.

The Shaolin Monastery is believed to be the most famous Buddhist temple in the world, attracting more than a million visitors 
annually and with total annual ticket sales of five million US dollars (Shahar, 2008). Situated in the Henan Province, one of China’s poorest provinces, this temple plays an important economic role for the entire region. The economic benefits of tourism at the temple are undeniable, but the influx of visitors has also spurred severe criticism. Shi Yongxin, Shaolin Monastery’s head abbot, reported in 2004 that several monks have turned into tourism workers rather than religious followers (China Daily, 2004). A kung fu school is operated within the temple, and meditation has become an extremely difficult task because of the increasing number of tourists and monks busy buying or selling souvenirs.

The number of visitors to the monastery can only be inferred according to the statistics of the city tourists because of the limited access to the attraction statistics. The monastery is located in Deng Feng city, which is a county level city. The monastery is a major attraction within the city. The website operated by Deng Feng Tourism Administration listed five recommended attractions on their home page, including the Shaolin monastery, a Buddhism related performance, and three attractions are not as famous as the monastery (Dengfeng Travel Information Net, 2016). Most people who know the Shaolin monastery are seldom aware that it is located in Deng Feng city. Therefore, most visitations reflected in the city statistics are attributed by the Shaolin Monastery, particularly in 1980s when the monastery is the only attraction of the city. Visitation information from the Provincial Yearbook from 1984 to 2014 have been collected even though some years failed to report exact numbers. Every province in China annually recorded their social and economic development in their provincial Yearbook. The visitation information was obtained from the section of general development of Dengfeng City. The visitors to the city are 2 million in 1984 (General Office of Henan Province, 1985), which reaches to 1 billion in 2014 (General Office of Henan Province, 2015). The Few Year Book reported the constitutions of domestic and 
international visitors. For instance, there are 12,219 international visitors out of 1.96 million overall visitors in 1986 (General Office of Henan Province, 1987). The monastery has encountered a massive amount of visitors for over 20 years, most of whom are domestic travelers, according to the city’s statistics.

The Shaolin Monastery faces an intensifying commercialization, in which tensions between economic gain and religion, and staged authenticity and tradition are apparent. Related academic evidence on the interaction and balance among the monastery’s different elements in the context of tourism development is lacking. Considering the spiritual importance of this monastery and the complexity of religious sites in China, understanding the multiple meanings in the context of Chinese culture is necessary in tourism development. To date, the materials on religious tourism in China remain scarce. Sacred spaces face a considerably increased pressure to strike a balance between the sacred and the mundane (Pavicic, Alfirevic, \& Batarelo, 2007; Raj \& Morpeth, 2007). The mismanagement of religious tourism sites often diminishes perceived authenticity (McKercher \& du Cros, 2002) and leads to dissatisfaction with the site in the worst case and subsequent lack of support for historical and cultural preservation (Levi \& Kocher, 2009). Understanding this issue from the Shaolin Monastery perspective is necessary considering the complex contemporary political, social, and economic context of China. Such understanding can aid in determining a sustainable management that accommodates both the religious preservation and the commercial development of Shaolin tourism. In light of the exploratory nature of this study, a focus group discussion among experienced Chinese tourism practitioners is selected as the most appropriate methodological tool.

\section{METHODOLOGY}

Based on the aforementioned research objectives, a qualitative inquiry that highlights "how social experience is created" (Denzin 
and Lincoln, 2008, p. 14) is suitable for the present study to obtain the meaning and interpretation of Chinese kung fu and Buddhism culture from natives. Such an inductive approach allows for the flexible development and presentation of multidimensional views from the field. A group of 58 practitioners and educators from the tourism and hospitality industry in Mainland China were invited to discuss the contestation of commercialization and sanctity in the Shaolin Monastery. The discussion aims to present the tensions and challenges between these two seemingly contradictory aspects for the sustainable development of tourism in sensitive religious sites. Table 1 presents the social demographic information of the participants. These Chinese practitioners and educators were invited in this study because of their Chinese identities and their managerial insights into the tourism industry. This study specifically focuses on the development of the Shaolin Monastery from the viewpoints of the practitioners and the general public. The discussions that represent the views of the monks and the local tourism administrations are included in a subsequent publication. Focus groups are employed to generate interpretive insights into the involvement of religious sites in tourism development because of the interactive feature of group discussions. The focus groups are typically composed of 5 to 12 participants (Langford \& McDonagh, 2003) who exchange ideas on a set of specific issues guided by a moderator. The moderator facilitates the conversations by posing questions and encouraging participants to elaborate their viewpoints without being personally involved in the discussions. The participants often have a dominant role in focus group discussions by actively contributing their opinions and responding to the conversation. In this regard, the focus group reduces the influence of the researchers on the participants. Compared with individual interviews, focus groups are invaluable in exchanging multiple individual ideas that can generate rich insights (Kamberelis \& Dimitriadis, 2005; Kitzinger \& Barbour, 1999).

The nature of culture is that it is collectively owned and shared by its members, which may be revealed more vividly through in-group 
discussions. Given such value, focus group discussions have been widely adopted in business to obtain comments on certain products (Langford \& McDonagh, 2003). In the current study, the participants hold different attitudes toward the commercialization of the Shaolin Monastery. In the focus group discussions, the participants initially stated and explained their respective attitudes, and then, they debated with one another using their respective supporting reasons. Multiple perspective thinking emerged from this exchange process. By the end of the debate/discussion, most groups not only presented rich information, they also collectively shared ideas on the sustainable development of the Shaolin Monastery. The findings section cited the group source of different opinions. The ideas that most groups agreed on similarly indicated their commonality with the wider population. Therefore, focus groups that explore insights and concerns on contested issues are deemed appropriate to explore the synergetic ideas on the contentious issues of the Shaolin Monastery development.

One major advantage of a focus group discussion is its capacity to effectively generate concise information from a comparatively large number of people over a short period. This study conducted 7 focus group discussions with 58 informants, which is a relatively noticeable number in qualitative inquiries. Seven moderators, all of whom were postgraduate students majoring in Tourism and Hospitality, were initially trained on the focus group method, the research purposes, and the process of becoming an effective moderator. Each trained moderator then led one focus group with 6 to 9 members involved in the same graduate studies of Tourism and Hospitality with the moderators. Discussions were audio-recorded with the consent of the informants, who were randomly assigned into seven groups. The recordings were transcribed for further data analysis. The average duration of a focus group discussion was approximately 63 minutes. The diversified demographic and the tourism- and hospitality-related experiences and 
knowledge were the basic sampling criteria used to gauge a broad thought process in relation to the tourism development of the Shaolin Monastery. The participants indicated a diversified background in terms of geographic location, age, gender, and occupation as well as work experiences in the tourism and hospitality industry (see Table 1). The average age of the participants was 34.4 years, and the ages ranged from 25 to 47 years. The average work experience of the participants in the tourism/hospitality industry was 11.9 years, and ranged from 1 to more than 20 years. Several participants worked in hotels or hotel management companies, whereas others worked in the frontline as tourism officers or travel agents. Several participants taught in tourism/hospitality institutions. The varied backgrounds of the participants facilitated the collection of multiple and rich points of view on this contested topic.

In addition, a number of issues shared in different groups can be used to indicate the view of the general public. For example, all of the participants agreed that the Shaolin Monastery is a component of their national culture because they learned about this monastery from history books, movies, television programs, dramas, and other sources. Most groups named some rituals and religious books pertaining to the monastery (Groups 3, 4, 5, and 7). Therefore, the Shaolin monastery is well-known to every family in China, and the shared opinions generated in this study can indicate the same perceptions toward the monastery as the Chinese population toward. Many participants also reported their collective memory of the Shaolin Monastery in the 1980s when the movie Shaolin Monastery was shown. Some group members mentioned their travel experiences to the monastery (Groups 3, 4, 5, and 6). From the perspective of the practitioners, most participants showed extensive experience in the tourism and hospitality industry. A total of 51 participants were from the industry, and 49 out of 51 were at the managerial level (see Table 1). Therefore, the information from these practitioners and educators represents the multidimensional perceptions on the tourism development of the Shaolin Monastery from 
both the general Chinese and the tourism industry perspectives.

Table 1. Informants’ Profile

\begin{tabular}{|l|l|l|l|l|l|l|}
\hline$\#$ & Group & Gender & Age & Position & Organization Category & Years of work experience \\
\hline 1 & Group 1 & Male & 40 & General Manager & Hospitality & 17 \\
\hline 2 & Group 1 & Male & 31 & Sales Director & Hospitality & 6 \\
\hline 3 & Group 1 & Male & 34 & Assistant of Sales Director & Hospitality & 12 \\
\hline 4 & Group 1 & Female & 40 & Financial Director & Hospitality & 17 \\
\hline 5 & Group 1 & Female & 40 & Sales Director & Hospitality & 20 \\
\hline 6 & Group 1 & Female & 37 & Sales Manager & Hospitality & 13 \\
\hline 7 & Group 1 & Female & 34 & Vice Manager & Hospitality & 12 \\
\hline 8 & Group2 & Female & 26 & Development Manager & Hospitality & 4 \\
\hline 9 & Group2 & Female & 33 & Human Resource Manager & Hospitality & 14 \\
\hline 10 & Group2 & Male & 39 & Financial Manager & Hospitality & 11 \\
\hline 11 & Group2 & Male & 33 & Assistant of General Manager & Hospitality & 16 \\
\hline 12 & Group2 & Female & - & Vice Director & Hospitality & \\
\hline
\end{tabular}




\begin{tabular}{|c|c|c|c|c|c|c|}
\hline 13 & Group2 & Male & 34 & General Manager & Hospitality & 9 \\
\hline 14 & Group2 & Female & 41 & Revenue Manager & Hospitality & 20 \\
\hline 15 & Group2 & Female & 28 & Teacher & Education & 2 \\
\hline 16 & Group3 & Female & 24 & SPG Coordinator & Hospitality & 2 \\
\hline 17 & Group3 & Male & 43 & Vice Manager & Tourism & 22 \\
\hline 18 & Group3 & Female & 25 & Supervisor of Service Quality & Hospitality & 3 \\
\hline 19 & Group3 & Female & 27 & Representative of Hotel Owners & Hospitality & 3.5 \\
\hline 20 & Group3 & Female & 25 & Teacher & Education & 2 \\
\hline 21 & Group3 & Female & 35 & Operation Director & Hospitality & 14 \\
\hline 22 & Group3 & Female & - & Vice Manager & Hospitality & 10 \\
\hline 23 & Group3 & Male & 24 & Teacher & Education & 1.5 \\
\hline 24 & Group4 & Female & 33 & Vice Director & Hospitality & 12 \\
\hline 25 & Group4 & Male & 39 & Engineering Director & Hospitality & 18 \\
\hline 26 & Group4 & Male & 34 & Vice Manager & Hospitality & 13 \\
\hline 27 & Group4 & Male & 29 & Guest Relationship Manager & Hospitality & 5 \\
\hline 28 & Group4 & Female & - & Chairman & Tourism & 24 \\
\hline
\end{tabular}




\begin{tabular}{|c|c|c|c|c|c|c|}
\hline 29 & Group4 & Male & 25 & Teacher & Education & 2 \\
\hline 30 & Group4 & Female & 35 & Staff & Tourism & 14 \\
\hline 31 & Group4 & Male & 40 & General Manager & Tourism & 18 \\
\hline 32 & Group5 & Male & 39 & General manager & Hospitality & 16 \\
\hline 33 & Group5 & Female & 32 & Manager of Public Relationship & Hospitality & 9 \\
\hline 34 & Group5 & Male & 47 & Director & Hospitality & 23 \\
\hline 35 & Group5 & Female & 38 & Financial Director & Hospitality & 19 \\
\hline 36 & Group5 & Female & 39 & Human Resource Manager & Hospitality & 21 \\
\hline 37 & Group5 & Male & 36 & Food and Beverage Manager & Hospitality & 13 \\
\hline 38 & Group5 & Male & 43 & General Manager & Hospitality & 17 \\
\hline 39 & Group5 & Female & 30 & Assistant of Chairman & Hospitality & 9 \\
\hline 40 & Group6 & Male & 39 & Manager & Tourism & 16 \\
\hline 41 & Group6 & Male & 29 & Vice Chairman & Hospitality & 7 \\
\hline 42 & Group6 & Female & 30 & Vice Manager & Tourism & 10 \\
\hline 43 & Group6 & Female & 34 & Sales Director & Hospitality & 14 \\
\hline 44 & Group6 & Male & 37 & Manager & Tourism & 17 \\
\hline
\end{tabular}




\begin{tabular}{|c|c|c|c|c|c|c|}
\hline 45 & Group6 & Male & 43 & General Manager & Tourism & 19 \\
\hline 46 & Group6 & Male & 36 & General Manager & Hospitality & 12 \\
\hline 47 & Group6 & Female & 26 & Human Resource Director & Hospitality & 4 \\
\hline 48 & Group6 & Female & 40 & Human Resource Director & Hospitality & 8 \\
\hline 49 & Group7 & Female & 45 & Department Head & Tourism & 20 \\
\hline 50 & Group7 & Male & 29 & Chief officer & Tourism & - \\
\hline 51 & Group7 & Female & 33 & Officer & Tourism & 6 \\
\hline 52 & Group7 & Female & - & Assistant of Manager & Tourism & 6 \\
\hline 53 & Group7 & Male & 35 & Manager & Hospitality & 10 \\
\hline 54 & Group7 & Male & 38 & Investment Manager & Hospitality & 15 \\
\hline 55 & Group7 & Female & 38 & Chairman & Hospitality & - \\
\hline 56 & Group7 & Male & 37 & General Manager & Hospitality & - \\
\hline 57 & Group7 & Female & 26 & Teacher & Education & 3 \\
\hline 58 & Group7 & Female & 33 & Lecture & Education & 9 \\
\hline
\end{tabular}

“_-"means missing information. 
The two authors independently analyzed the transcripts using Nvivo for cross-validation. The authors first read the transcripts several times to familiarize themselves with the data. Concepts and dimensions were assigned whenever appropriate for open coding, and the transcripts were pursued line-by-line. After the emergence of a large amount of primary codes, several codes were grouped together based on their similarities and associations. Strauss (1987) called this practice axial coding. Salient themes gradually emerged from all of the axial codes. After conducting the systematic coding process (Glaser \& Strauss, 1967), the authors compared the two sets of codes and discussed the most appropriate codes and themes until a consensus was reached.

\section{FINDINGS}

Figure 1 shows that the analysis spurred the development of three major themes, namely, "Shaolin as a representation of Chinese culture," “Tensions between sacred values and commercialization,” and "Shaolin kung fu as a carrier of Buddhist and Chinese values." The discussion on "Shaolin as a representation of Chinese culture" included the sub-themes of "Fitting into Chinese philosophy” and “Being accepted worldwide as an important element of Chinese culture.” Most discussions were conducted around the second theme ("Tensions between sacred values and commercialization") because this is the most contested issue of the monastery as a carrier of religion. The views raised by the participants are best presented in three categories, namely, expectation, problem, and suggestion, in which the participants discussed their expectations toward the Shaolin Monastery, the current problems associated with tourism development in Shaolin, and the suggestions to obtain a balance between commercialization and sanctity of the religious site in tourism, respectively. The same logic was applied to the third theme ("Shaolin kung fu as a carrier of Buddhist and Chinese

values”). Nevertheless, it is inevitable to obtain several overlaps in the analysis among several sub-themes. For example, the 
solicitation of monks is both a type of misconduct and a representation of the aggressive pursuit of economic profits.

Figure 1: Analytical codes

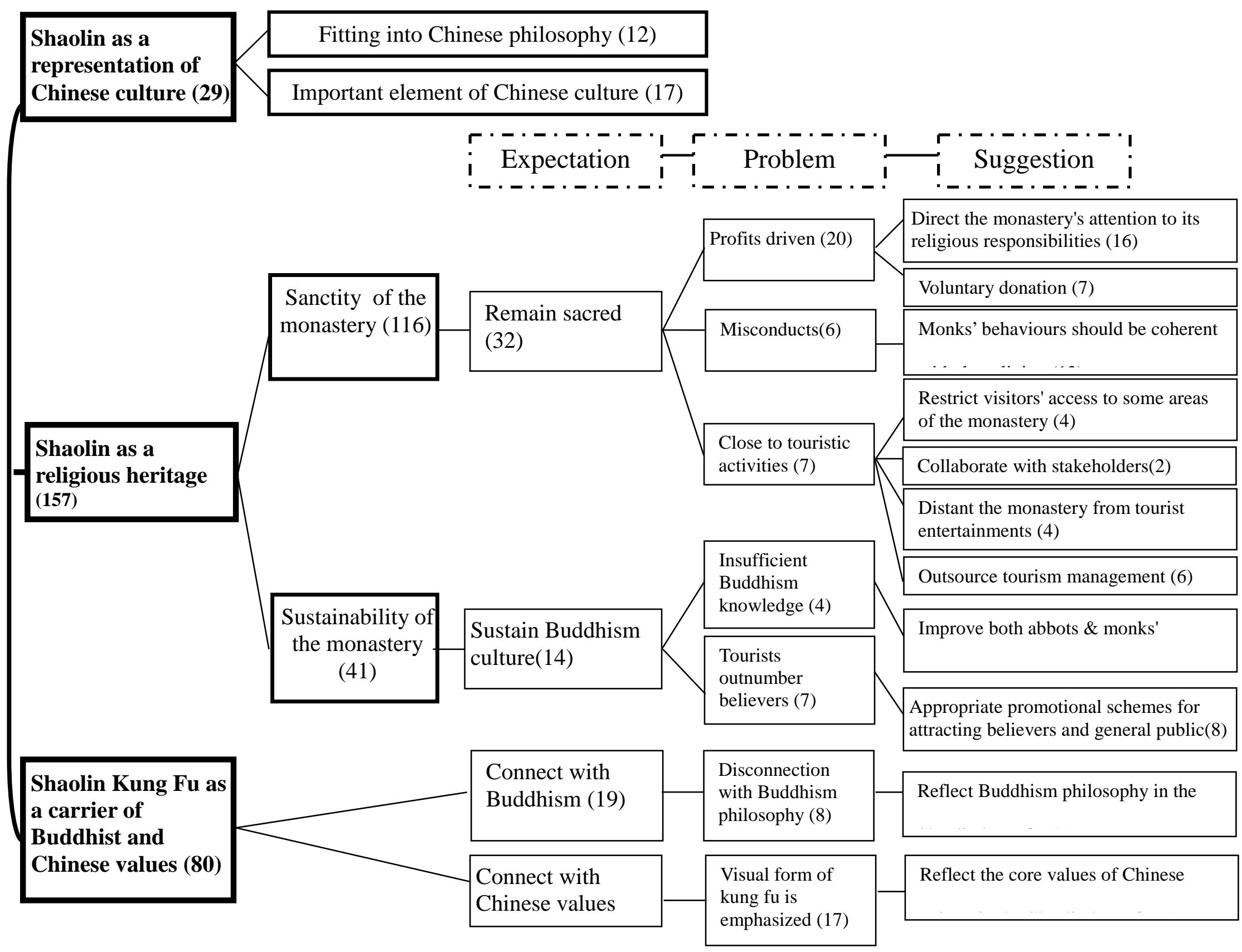




\section{Shaolin as a Representation of Chinese Culture}

Almost all informants suggested that Buddhism and kung fu are important components or representatives of Chinese culture. They understood culture as a prolonged accumulation and consolidation of life experiences and thought processes and wisdom collectively processed by its members. Culture is reflected across all aspects of life, including arts, festivals, and daily practices, such as diet, greeting, and language. Culture is also commonly shared among a group of people, and it differentiates a group from others. The inclusive nature of culture induces the differentiation of social groups, ranging from as small as a family to large units, such as a company, zone, region, and country. The participants mentioned that shared values and thought patterns facilitate communication and cooperation among people in the same cultural group. The informants from Groups 1, 3, 4, 5, and 7 identified Confucianism as the central philosophy that constitutes Chinese culture, with "mean/moderate" (中庸), which is the neutral and moderate attitude embodied in ubiquitous Chinese behaviors and emotions, as its key ideological value. For instance, being modest, hardworking, and cooperative are highly valued in the Chinese context.

The respondents suggested that "moderate” thinking is also reflected in Buddhism and kung fu. Maintaining a peaceful mind and neutral attitude are both valued in Buddhism and Confucianism. Therefore, Buddhism-coherent behaviors are expected in Shaolin and should be prioritized over profit-making, as reflected in the following statement:

"We Chinese follow many conventional and unconventional rules in our society so we do not deviate significantly from the social norms. A religion should uplift common beliefs and central philosophies for its practitioners to follow. When deviation from the shared values occurs, such as the active involvement of monks in donation solicitations, it is regarded to 
be inappropriate in the practice of religion.” (A male from Group 7)

The same Chinese philosophy also applies to kung fu:

"Kung fu is another distinct culture present not only in the form of fighting gestures, but also in its underlying philosophies, such as perseverance and endurance. A common understanding among the kung fu community is that a good kung fu master should excel in both qualities.” (A male from Group 3)

Based on the aforementioned quotes, following the traditional routines of religion is highly expected in light of the Chinese "mean/moderate” philosophy. Religions, including Buddhism, Taoism, and others, were proposed as preeminent representation of the Chinese culture. This idea is commonly reflected in Chinese rituals, such as praying for good fortune and job promotions through religious activities, including burning incenses, visiting religious sites, and adhering to vegetarian diets. The intangibility of kung fu refers to its underlying values, such as perseverance and endurance. However, the public is better informed of the visual presentation of kung fu.

Chinese kung fu becomes significantly more popular in both domestic and international movies. Many kung fu training centers are established in the United States to promote Chinese kung fu. Several participants from Groups 1, 3, 4, and 7 commented that "Shaolin kung fu has been attractive to foreigners" and “...is regarded as a representation of Chinese culture. Whenever referring to kung fu, people immediately associate it with China. It is a showcase of Chinese culture." One informant from group 1 expressed his emotional attachment to Chinese kung fu, "We admire Chinese kung fu and regard it as a culture that the whole nation should be proud of."

\section{Tensions between sacred values and commercialization}

The authentic sanctity of the monastery is highly expected by all the seven focus groups. All 
groups confirmed that the overall atmosphere within/around the Shaolin Monastery should be sacred because this monastery is primarily a religious heritage. They suggested that a religious site should never forget its original purpose throughout tourism development. Thus, a temple should principally be a place for monks to cultivate their minds and strengthen their moral values by comprehending doctrines and disseminating Buddhist philosophies among its believers. The sacred nature of this specific religion contributes to its inexplicable charm to both believers and non-believers. This aspect motivates visitors to visit temples to practice Buddhism and to fulfill their spiritual needs. One informant in group 2 shared his experience visiting a temple in Japan: "I visited a temple in Japan, which opens to the public for visits and pilgrimages. Despite the presence of visitors in the temple, the monks there strictly followed their religious routines and were highly focused on their daily practices and rituals. I was in awe of their sincerity toward their religion and felt completely immersed in the religious atmosphere." Another participant from Group 5 also expressed a similar experience in the Penang, Malaysia: “The pious atmosphere made me forget about all my worries. It was a totally spiritual experience for me." Such statements represent people's expectations toward religious sites.

In contrast to the sacred atmosphere, the participants regarded the monastery to be overcommercialized in three aspects: aggressive pursuit of economic profits, misconduct of monks, and close proximity between tourist activities and religious sites. The aggressive pursuit of economic gains, which is in conflict with the holiness of religion, was raised because of the overcommercialized development of the Shaolin Monastery. These profit-driven activities include the excessive participation of the monastery in business activities, the priority on tourist needs because of potential benefits, or the inappropriate collection of money. For instance, several tourist activities, such as tea appreciation and kung fu shows, were launched to cater to 
the influx of tourists contributing to the income of the monastery. In another example, Buddhism traditionally collects donations from its followers for temple maintenance, religious development, and charitable activities for the benefit of the larger society. Donations should be given voluntarily without any pressure from the monastery. However, the participants mentioned that some members of the media reported several past incidents of monk misconduct as they pressure visitors for donations. Such solicitations are considered inappropriate and in conflict with the doctrines and common practices of Buddhism. Several informants shared their unpleasant experiences with Shaolin Monastery monks who forced them to donate money; this behavior raises questions about the sanctity and holiness of religion. These narratives suggested that the misconduct of monks and their active participation in profit-driven activities have shaken the respect and positive feelings of the public toward the Shaolin Monastery.

A suggestion to solve aggressive perusing economic profits is to direct the monastery's attention from financial profits to its religious responsibilities. A participant in Group 6 offered an alternative approach based on his personal experience in Malaysia: "I visited a mountain in Malaysia on which many Buddhist temples are established. Different from the Shaolin Monastery, which places donation boxes everywhere and arranges a monk to stand by each box, those in Malaysia built pagodas that can only be reached by climbing stairs. Believers should climb all the way up to donate their money and burn incense." Such an indirect donation collection is in accordance with the voluntary principle suggested as a reference to the Shaolin Monastery.

The second problem reported on commercialization in associated with the misconduct of monks. Their behaviors reflect the image of the monastery and the perceived core values of their religion; thus, the manner in which they behave significantly affects the perceptions of people on 
both the religion and the monastery. The monks are expected to cultivate their minds with Buddhism philosophies and to behave in a moderate and peaceful manner. However, a few participants noted the unconventional behaviors of monks, such as playing games on their iPhones and persuading visitors to donate more money. Restricted moral standards are expected of the monks; thus, their behaviors should be coherent with the expectations to live out the authentic and original goals of their religion.

The third problem the participants mentioned is not against tourist activities, but against their close distance to the core religious sites. The close proximity of the religious site and the tourist activities further amplified the conflict between the commercialization and sanctity of the Shaolin Monastery. An informant learned during his trip that tourist entertainment activities, such as KTV, majiang (mahjong), and restaurants, were located next to the Shaolin Monastery. This situation erodes the sanctity of the temple. Although the discussants were not in favor of prohibiting tourist activities, they urged the tourists to consider the locations of such nonreligious activities. Several participants further suggested that the difference between the Shaolin Monastery and other secular tourist attractions lies within the religious features of the former. " $A$ temple is a sacred place carrying much admiration from the public" (A female from Group 5; similar statements were also provided in Groups 1, 2, 3, 4, and 7).

Maintaining a distance from recreations and collaborating with other stakeholders are suggested to allocate the activities better. In the view of the informants, the core areas of the temple, such as the Chan Hall and Sutra Collection Pavilion, should not be open to visitors. The monks normally practice their daily meditation in the Chan Hall, which can be disturbed by visitors. "The leisure function of the temple for the use of visitors is in conflict with the basic nature of the monastery, which is primarily a site for the monks' meditation" (a female from 
Group 7). Several tourists related that the arrangements are not solely decided by the monastery itself, but by the collaboration among various stakeholders, such as the monastery, the government, and the local community. One participant in Group 1 suggested such a collaboration, and his focus group agreed that "The holy atmosphere of the temple was affected by the nearby constructions, even though the temple has nothing to do with these entertainment activities. Obviously, maintaining peace and a holy environment is not only the temple's responsibility but requires the collective effort of the local community.” The informants further suggested distancing religious sites from tourist entertainment and restricting visitor access to a few areas of the Shaolin Monastery in order to sustain its spiritual nature. Several respondents have also suggested hiring a professional organization that can focus on developing a sustainable tourism in the Shaolin Monastery; in this manner, the monks can focus on their religious duties. The monks' direct involvement in the tourism business is one of the major issues mentioned related to the perception of authenticity.

\section{Sustainability of the Monastery}

The second sub-theme is related to the sustainability of Shaolin Monastery, which relies on maintaining the Buddhist culture and its numerous followers. Considering the current tourism activities and the monastery development, the participants were concerned about the sustainability of the Shaolin culture. Such concerns were expressed in the following statement: "Opening the Shaolin Monastery to visitors is acceptable for me. However, the Shaolin Monastery should protect its core values for the sustainability of its culture. What can they offer to tourists in the next 10 years? Changes need to be made to the current practices for the sustainability of the temple" (a male from Group 5). Thus, maintaining the sanctity and the religious identity of a religious site, such as the Shaolin Monastery, is necessary to maintain its 
charm. The participants suggested that actions should be undertaken to protect the religious identity of the Shaolin Monastery.

In doing so, sufficient knowledge of Buddhism is expected of both the abbots and monks. The expectation on the abbots was reflected from the following statement: "A good abbot should possess solid knowledge of Buddhism, which takes time to develop. How can these young abbots accumulate sufficient knowledge at such young ages to lead other monks and believers?” (a male from Group 5). Similar problems in other monasteries are also mentioned by the participants in Group 3: "Nowadays, most temples adopt a commercialized promotion, which attracts only visitors instead of believers." Another group mentioned that most abbots are only approximately 30 years old. Another informant reported his disappointment regarding the knowledge of an abbot he encountered in a monastery: "Honestly speaking, I was not impressed with his knowledge of Buddhism and I do not think he possessed the virtues that are worth my respect." The other participants also expressed similar concerns on the monks' knowledge of Buddhism. Corresponding suggestions on this problem include improving both the abbots and monks' knowledge, which should be coherent with religious expectations. Acquiring such wisdom is reportedly a result of a long and arduous path (Group 6); thus, the abbots' young age is likely to raise doubts about their Buddhism-related knowledge. The abbots' knowledge cannot only preserve religious knowledge, but also tend to generate a more authentic perception toward the Shaolin among tourists.

Many participants are also concerned about the number of dedicated believers that may have been affected by the overcommercialization of the Shaolin Monastery. One respondent from Group 7 shared such concern: "Our understanding toward Buddhism is less substantial than those of previous generations, such as our parents. This understanding will likely be further 
diminished in future generations." Similar concerns emerged in Groups 3, 5, and 6. Based on the aforementioned comment, the general public's knowledge of Buddhism may depreciate over time; thus, sustaining Shaolin tourism can become a challenge. However, pilgrims tend to visit temples more persistently than other visitors do. A dedicated believer may visit a temple at least two or three times annually, whereas other visitors may only visit the site once in their lives. Thus, educating the visitors regarding the religion is a means of sustaining Shaolin tourism because they can hardly experience a religious atmosphere in the temple as a result of overcommercialization. The participants regarded religion as an aspect that can potentially enhance the appeal of the Shaolin Monastery and that can lead to its sustainable development.

Correspondingly, strengthening the promotion of Buddhism to both believers and tourists is suggested. The development of Shaolin tourism should promote the wholeness of the Shaolin culture, in which the essence of Buddhism is reflected. The Shaolin Monastery is a holy place for the Buddhist community in China. Numerous historical and legendary stories of the Shaolin Monastery that reflect the core values of Buddhism can be shared with visitors to arouse their interest. However, the participants still criticized the current promotional strategies of the Shaolin Monastery: "The Shaolin Monastery is different from a commodity. Common practices, such as using several gimmicks to promote a commercial product, are unsuitable for the Shaolin Monastery because of its religious nature. The public is unlikely to accept such a practice if it is executed" (Group 2). Health has also become an increasingly major concern of the people. "Developing several health-related products to promote a healthy lifestyle is a good opportunity for the Shaolin Monastery” (Group 7). Accordingly, the promotion of a religious temple should be executed with caution and highly differentiated from ordinary tourist attractions because "the general public would not tolerate overcommercializing a religion in the same way as a regular 
consumer product" (Group 7). The promotion and showcase of the religion-based Shaolin culture is suggested to achieve a balance between the sacred and the mundane.

\section{Shaolin Kung Fu as a Carrier of Buddhist and Chinese Values}

Shaolin kung fu is assumed to connect with Buddhist philosophy. This type of kung fu is mentioned as a unique element differentiating the monastery from other religious sites as this martial art is unique to Shaolin. Several informants recalled their memory of the national passion for Shaolin kung fu after the movie Shaolin Monastery was shown, which built the global reputation of the monastery. However, problems are also noted in such enthusiasm for kung fu. The informants discussed the disconnection between the Shaolin kung fu and Buddhism in the current development, which considerably emphasizes secularity. One of the special features of the Dhyana or "Chan" School of Buddhism is that it addresses internal meditation and enables people to acquire a peaceful mind through the practice of Shaolin kung fu. A male informant from Group 3 mentioned that "Buddhism and kung fu are integral parts of the Shaolin culture." The pursuit of a peaceful mind in meditation in Buddhism is also included in the Shaolin kung fu philosophies and fighting gestures. Several participants identified the deficiency of kung fu performance: "Unlike Western boxing, which employs the philosophy of defeating opponents at every shot, (Shaolin) kung fu is more about fighting a strong opponent in a flexible way" (Group 3). However, such a connection is unclear in the current development of Shaolin tourism.

The participants also viewed the relationship between Shaolin kung fu and Chinese culture as insufficiently promoted. They frequently mentioned that masculinity, perseverance, and endurance contribute to the appeal of kung fu, and kung fu should be more intensively promoted in tourism. To cater to the large number of tourists, daily kung fu shows within the monastery are performed by a group of bareheaded students dressed as monks from a local kung fu school. One 
informant critiqued that "the Shaolin kung fu is currently presented as a simple gesture show without extensively revealing its core values." A similar idea was expressed by another discussion group that "the Shaolin Buddhism culture is mainly presented in the form of kung fu shows and physical buildings in this current tourism development. Architecture and shows are only signs and symbols of the Shaolin Buddhism culture. They do not represent the entire Shaolin philosophy” (Group 5). To sustainably develop Shaolin tourism, connecting Shaolin kung fu to both religious philosophy and Chinese values is suggested.

\section{DISCUSSION}

\section{Dilemma of Commercialization and Sanctity}

This study aims to explore the meanings of the Shaolin Monastery, which is a conglomeration of the Shaolin kung fu, Buddhism, and tourism, as a carrier of Buddhism and Chinese culture in tourism development. Furthermore, it intends to deepen the understanding of the balance between commercialization and sanctity in the context of the monastery. Seven focus group discussions involving 58 Chinese tourism practitioners and educators were conducted to achieve the research objectives. Contentious issues involving the Shaolin Monastery were discussed from the viewpoints of the practitioners and the general public. The participants elaborated on the overcommercialization problems along with their expectations of the Shaolin conventional values. The unbalanced development of the Shaolin Monastery in terms of commercialization and sanctity engendered significant concerns among the respondents. In their view, the Shaolin Monastery's heavy reliance on commercialization undermines its religious value and authenticity. Overcommercialization is identified not only as the cause of the negative effects on the atmosphere and sustainability of the Shaolin culture, but also the factor undermining the essence of Shaolin kung fu. 
Based on the results, a balanced religious tourism development model is proposed in Figure 2. The model presents the dilemma of managing religious tourism with the struggles of balancing the commercialization and sanctity of a religious site. Ideally, a religious site should be maintained at the optimal level of commercialization and sanctity. At this balanced state, the religious site can present its spiritual integrity with the support of tourism to attain financial viability and to promote religion. With the optimal development of religious sites, tourists can experience the spirituality of religion, and the core values of religion are not jeopardized by tourism development. The optimal development of a religious site is a matter of maintaining a balance between religion- and profit-driven management approaches. The former should be the core consideration in managing religious sites. However, the current state of the Shaolin Monastery suggests otherwise as the profit-driven approach dominates the focus on religion. The high level of commercialization overshadows the sanctity of the religion, which disenchants the monastery to certain extent. 
Figure 2. A balanced model of religious tourism development

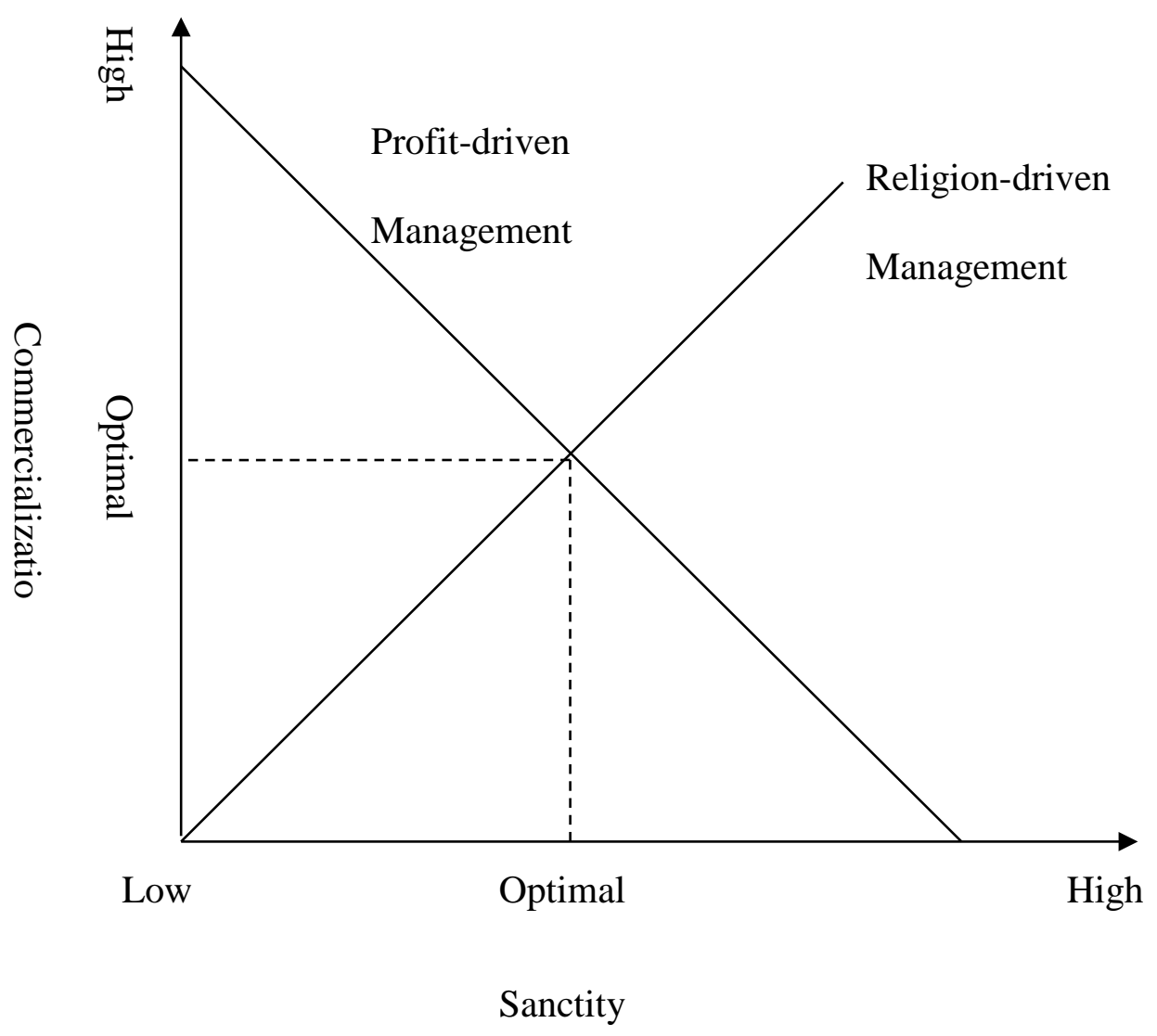

Previous studies have indicated that religious sites are socially constructed as being sacred (Belhassen, Caton \& Stewards, 2008; Bremer, 2006). The participants enumerated several items related to the monastery that deconstructed the sacred sense of the site, including the aggressive pursuit economic profits, the misconduct of monks, and the close proximity between tourist activities and religious sites. These problems echo the assertion of a previous study that tourismrelated facilities can damage the religious sense of place (Singh, 1997; Shinde, 2007). Although the participants are not against the tourism facilities in the monastery, they warned that the close distance between the religious site and the tourist activities can reduce the appeal of the monastery as a sacred Buddhist site. This finding rejects the common notion that 
commercialization is merely destructive and negative (Singh, 1997; Shinde, 2007).

Commercialization contributes to the financial income and popularity of the monastery, which are important to sustain the daily operation of the religious site and to promote the religion to a larger audience to increase followers. Therefore, commercialization should be regarded as a means instead of an end in developing religious tourism.

By perceiving authenticity from the socially constructed perspective, the conflict between commercialization and sanctity become less incompatible. By taking a close look at what the participants are against at, the criticism originates from the apparent and direct involvement of the temple in the business of tourism in the forms of the direct solicitation of donation or the close proximity of tourist activities to religious sites. These examples echo Olsen’s (2006) argument that the physical effects of overcrowding destroy reverent and peaceful atmospheres. The monastery should maintain a sacred image of a religion. Similar argument is also highlighted by McKercher \& du Cros (2002) wherein the mismanagement of religious tourism sites often reduces perceived authenticity. In line with the suggestion of absolutely abandon tourism business, indirect involvements are suggested by the respondents for the Shaolin to participate in tourism as confirmed by their description of the alternative managements of other Buddhism temples. The indirect means of collecting donation can meet the financial needs of the temple, as well as avoid creating the feeling to its visitor that such behavior directly conflicts with the Buddhism doctrine. Therefore, commercialization does not destroy the sense of authenticity for a religious site, overcommercialization does.

Some indicators should be developed to identify if the commercialization goes too far on a religious site. In addition to the physical attributes of a religious site, the people representing the religion at the site should also be included in the measurement. In the case of the Shaolin, monks 
are one of the key representations of Shaolin culture. Thus, encounters with them are expected by tourists at Shaolin. However, the deviation of monk behaviors from what tourists expect can also jeopardize the authentic image of Shaolin. A further study on identifying the key indicators of overcommercialization on a religious site is important to site management.

To maintain the socially constructed authenticity, deeply exploring its religious cultural backgrounds in seven focus groups is considered necessary. Religious tourism can be sustained in the Shaolin Monastery by restoring its sanctity, reflecting both Buddhist and Chinese values in tourism and promoting the essence of kung fu to tourists. These suggestions from seven focus groups of tourism practitioners also matched the suggestions made in previous studies (Timothy and Olsen, 2006). Sustaining the religion should be the goal of all practices in the development of religious tourism. The monastery's current tourism management is directed by a profit-driven approach, which is the major cause of the site's overcommercialization. A religion-driven management approach is implemented to redirect the attention of the monastery to its core values. This approach does not intend to abandon tourism development; rather, tourism development is viewed to be important and beneficial to the monastery to communicate its religious beliefs to a large population. However, if profit-making overshadows religion in the development of religious tourism, then the sanctity and core values of religion, which are the key attractions for tourists, are lost in the process. The ultimate goal of developing religious tourism should be to utilize tourism as a means of strengthening the religion.

Overall, the views of the participants are homogeneous to a certain degree, which itself is an important finding. The discussion nature of the groups and their tourism business management backgrounds are partly attributed to such a homogeneous finding. In the focus group discussion, the participants normally stated their own opinions at the beginning and each provided the 
reasons to support their opinions. Through such an idea exchanging process, participants tried to revisit their own opinions by including the opinions of others. The findings from individual interviews may be different from this group discussion because the former can follow individual opinions, whereas the latter enables the idea exchanges and provides spaces to mitigate two contested directions. As the participants highlighted “mean (中庸)” as the central philosophy of Chinese culture, they adjusted their own positions in the group communication. Each group and each group member contributed to discussion on the contestation topic by enriching their own acceptable criteria and possible solutions. The findings presented in this paper are the accumulated thoughts from each participant. Furthermore, the discussions on the Chinese culture are homogeneous from the public perspectives because of the collective and shared nature of a culture.

\section{Religion and Tourism}

In the context of contemporary China, the complex separation of secular tourism from spiritual tourism has been indicated because the former is closely bound to its political, social, and economic conditions (Özkan, 2013). Accordingly, Chinese visitors to religious heritage sites are highly aware of the rapid and safe means of transportation, commercialization, secularization, and government intervention in restoring and promoting both the national and local identities. The religious tourism sites in China are often promoted to fulfill spiritual needs and to educate visitors about patriotism and China’s national history (Özkan, 2013).

Given the emergence of religious tourism, several discussions of pilgrimage and religion tourism have been initiated in the past literature. Several scholars (Cohen, 2003; Rinschede, 1988; Smith, 1992) have suggested that pilgrimage and religion tourism are at the two ends of a continuum, with the former referring to traveling to religious destinations primarily for religious 
pursuits and the latter pertaining to traveling to religious sites principally for personal pleasure. Regardless of the category to which tourists belong, holy experiences are expected by all of the concerned travelling parties, including pilgrims, tourists, and those in between (Prahalad \& Haamel, 1990). Such holy experiences are explained in Olsen's (2013) study as expected emotional experience and in Shackley's (2005) research as spiritual needs. Therefore, retaining the religious charm of the Shaolin Monastery is vital to sustain its tourism development.

Olsen (2003) mentioned that not every religious tourism site is considered sacred. The participants view the Shaolin Monastery as one such site despite its potential to regain its charm. This monastery is widely believed to be the most famous Buddhist temple in the world (Shahar, 2008). Its popularity can help broadcast the Buddhist message and values to a broad community via tourism. Thus, tourism is a channel of communication between religious sites and the interested public. Although commercialization may be inevitable in tourism development, overcommercialization should be avoided and the sanctity of the religious site should be protected. Doing so is necessary to sustain tourism and to promote the ultimate purpose of developing tourism at a religious site.

\section{Religion and Culture}

The analysis of the meanings of the Shaolin Monastery as a carrier of Chinese culture indicated that its religious values share the same core values as Chinese Confucianism, particularly the "moderate" philosophy. The Shaolin Monastery is evidently regarded as a representative of Chinese culture. This finding echoes previous studies that have examined the appeal of the monastery (Morris, 2004; Shahar, 2008). The same finding also confirmed the finding of Andriotis (2009), in which contemporary pilgrimage experiences include the elements of culture, secularity, nature, and religious devotion. China's religious tourism has seldom been 
the focus of studies in the tourism and hospitality literature. Research on the Shaolin Monastery is even scarce, which contradicts its popularity among the general public.

The focus group discussions reflected that Shaolin tourism cannot depart from the broad Chinese cultural context because Shaolin is a component of the national culture and its presentation in tourism should reflect core Chinese values. A similar association between religion and general culture was also observed in the studies of Shackley (2005) and Özkan (2013), in which the discussion of religious issues is closely linked to culture. In the case of the Shaolin Monastery, the unconventional or deviant behaviors related to it are unacceptable to the participants who value the "moderate" Confucian philosophy. However, the integration of Chinese culture in the development of religious tourism remains unexplored. Although past literature have argued that religion and tourism are interlinked because the proper use of religious resources in tourism development can benefit both parties (Ambrósio, 2007; Kaszowski, 2000; Stausberg, 2011); furthermore, the discussion of religion, culture, and tourism in the same context has not been established.

In line with the literature, the continuity of religion is another major concern of the participants (Levi \& Kocher, 2009; Nolan \& Nolan, 1992). Knowledge on Buddhism and its promotion to both believers and tourist groups are suggested. Shackley (2002) indicated that this lack of spiritual depth in religious tourism sites often results in leisure tourists outnumbering worshippers. As a religion, Buddhism is based on achieving a state of enlightened consciousness for which the achievement of wisdom is an essential feature (Timothy \& Olsen, 2006). Consistent with this concept, sufficient knowledge of Buddhism and dedicated behaviors of both the abbots and monks are expected. Buddhist practitioners often visit the temple multiple times a year, whereas leisure tourists normally visit the temple only once; hence, visitor motivations for 
religious sites tend to be complex and are often not worship-related (Hughes et al., 2013;

Shackley, 2005). Therefore, the respondents suggested exerting more marketing efforts to attract religious believers and to cautiously draw sightseeing tourists.

\section{Religion and Kung Fu}

Shahar (2008) indicated that the Shaolin Monastery’s connection to kung fu, a worldfamous Chinese fighting technique, is the major reason for Shaolin’s popularity. Since the early 1960s, the temple has been portrayed in many movies as a hub for traditional martial arts. Practiced in China since the first century BC, similar fighting techniques continue to have important religious, health-related, and political roles in Chinese society (Shahar, 2008). Although closely related to Buddhism, kung fu is reported (Groups 2, 3, 5, 6, and 7) to be a more important tourist attraction than religion relative to the Shaolin Monastery.

Kung fu itself is considered to have become a multifaceted concept within the temple, from "health and well-being to theatrical performance, from a competitive sport to religious selfcultivation, from self-defense to armed rebellion” (Shahar, 2008, p. 202). Kung fu’s connections to Buddhism and Chinese philosophies have been vividly reflected in the dialogues. Although kung fu has become a salient attribute of Shaolin tourism, the promotion of religious beliefs and Chinese values in kung fu is lacking. The current practice is to heavily focus on promoting the visual and entertainment values of kung fu without communicating its essence to tourists. In contrast to the monastery, kung fu is an active form of tourism, which is often regarded by visitors as interesting and enjoyable. Promoting the Buddhist and Chinese values through kung fu is more likely to be effective in attracting people's attention.

\section{CONCLUSION}

Based on the case of a famous Chinese monastery, the findings of this study reflect the 
dilemma involving the commercialization and sanctity of Shaolin tourism. Sustaining the religion is regarded as the key to all tourism practices. The connections of religion to tourism, culture, and kung fu are identified to facilitate the conceptual understanding of religious tourism development in China and the practical implications of the study. The management suggestions can be modified to suit the nature and context of other religious sites. The findings from previous studies, such as the overarching of culture and religion (Andriotis, 2009), highly valued sacred experience (Prahalad \& Haamel, 1990; Singh, 1997; Shinde, 2007), and continuity of religion (Levi \& Kocher, 2009; Nolan \& Nolan, 1992), have also been noted in the Chinese Buddhism context. Connecting these findings in a country where only a few studies on the issues related to religious tourism have been conducted contributes to international scholarship. This study is not against commercialization and tourism development at a religious site; however, we advocate a religious-centered management approach when developing tourism at religious sites.

This study includes several limitations. First, the focus group discussions are only audiorecorded. Thus, linking the quotes with the particular contributor is impossible despite the participants' rich industry experience that may guide them in explaining their views. Video recording is clearly preferred in future research. Second, this study is firmly embedded in the context of the Shaolin Monastery and the related cultural and religious principles. A study in another context concerning the same topic may yield different results.

Further research can investigate the implication of the results of this study for the specific management of the monastery. The results of this study can be compared with those on other religious sites in other contexts. Our results also help understand whether differences in sites related to their religious affiliation exist. A comparison between Christian, Islamic, and Buddhist sites is particularly interesting as well. Finally, further studies can investigate the perception of 
the Shaolin Monastery site from a Western perspective. The Chinese respondents frequently mentioned that the Shaolin Monastery is famous for the related movies and the kung fu-inspired pop culture in the West. Investigating this issue can better explain the issue of religious tourism from a cross-cultural scale. 


\section{References}

Ambrósio, V. (2007).Sacred pilgrimage and tourism as secular pilgrimage. In N. D. Morpeth\& R. Raj (Eds.), Religious tourism and pilgrimage management: An international perspective (pp. 78-88).Wallingford: CAB International.

Andriotis, K. (2009). Sacred site experience.A phenomenological study. Annals of Tourism Research, 36(1), 64-84.

Attix, S. A. (2002). New Age-oriented special interest travel: an exploratory study. Tourism Recreation Research, 27(2), 51-58.

Bailey, N. (2008). The challenge and response to global tourism in the post-modern era: the commercialization, reconfiguration and mutual transformation of Habana Vieja, Cuba. Urban studies, 45(5-6), 1079-1096.

Bandyopadhyay, R., Morais, D. B., \& Chick, G. (2008).Religion and identity in India's heritage tourism. Annals of Tourism Research, 35(3), 790-808.

Beijing Review (May 25, 2006). Should the sanctity of a temple be commercialized? Beijing Review, 49 (21), 44-45.

Belhassen, Y., Caton, K., \& Stewart, W. P. (2008).The search for authenticity in the pilgrim experience. Annals of Tourism Research, 35(3), 668-689.

Bianchi, R. (2003). Place and power in tourism development: tracing the complex articulations of community and locality. Pasos, 1(1), 13-32.

Bremer, T. S. (2001). Religion on display: tourists, sacred place, and identity at the San Antonio missions (Doctoral dissertation, Princeton University).

Bremer, T. S. (2006). Sacred spaces and tourist places.In D. J. Timothy \& D. H. Olsen (Eds.).Tourism, religion and spiritual journeys (pp. 25-35). Abingdon: Routledge.

Britton, S. (1991). Tourism, capital, and place: towards a critical geography of tourism. Environment and planning D: Society and space, 9(4), 451-478.

Cazaux, F. (2011). To be a pilgrim: A contested identity on Saint James's way. Tourism: An International Interdisciplary Journal, 59(3), 353-367.

ChinaDaily (2004).Shaolin Monastery turns money-making machine.Retrieved on April $15^{\text {th }}$, 2013 from http://www.chinadaily.com.cn/english/doc/2004-11/22/content_393567.htm.

Chhabra, D. (2010). Back to the past: a sub-segment of Generation Y's perceptions of authenticity. Journal of Sustainable Tourism, 18(6), 793-809.

Cohen, E. (1979). A phenomenology of tourist experiences. Sociology, 13(2), 179-201.

Cohen, E. (1988). Authenticity and commoditization in tourism. Annals of Tourism Research, 15(3), 371-386.

Cohen, E. (1992). Pilgrimage centres: Concentric and eccentric. Annals of Tourism Research, 19(1), 33-50.

Cole, S. (2007). Beyond authenticity and commercialization. Annals of Tourism Research, 34(4), 943-960.

Coleman, S., \&Eade, J. (Eds.). (2004). Reframing pilgrimage: Cultures in motion. London: Routledge.

Collins-Kreiner, N. (2010). Researching pilgrimage: Continuity and transformations. Annals of Tourism Research, 37(2), 440-456. 
Collins-Kreiner, N., \&Gatrell, J. D. (2006). Tourism, heritage and pilgrimage: the case of Haifa's Bahá'í Gardens. Journal of Heritage Tourism, 1(1), 32-50.

Collins-Kreiner, N., \&Kliot, N. (2000). Pilgrimage tourism in the Holy Land: The behavioural characteristics of Christian pilgrims. Geo Journal, 50(1), 55-67.

Collins-Kreiner, N., Kliot, N., Mansfeld, Y., \&Sagi, K. (2006). Christian tourism to the Holy Land: Pilgrimage during security crisis. Aldershot: Ashgate.

Connell, J. (2006). Medical tourism: Sea, sun, sand and surgery. Tourism Management, 27(6), 1093-1100.

Della Dora, V. (2012). Setting and blurring boundaries: Pilgrims, tourists, and landscape in Mount Athos and Meteora. Annals of Tourism Research, 39(2), 951-974.

Denzin, N. K., \& Lincoln, Y. S. (2008).The landscape of qualitative research (3rd ed.). Thousand Oaks, Calif.: Sage Publications.

Dengfeng Travel Information Net. (2016). Recommended attractions. Retrieved from: http://dflyw.cn/index.aspx

Digance, J. (2003).Pilgrimage at contested sites. Annals of Tourism Research, 30(1), 143-159.

Digance, J. (2006).Religious and secular pilgrimage. In D. J. Timothy \& D. H. Olsen (Eds.), Tourism, religion and spiritual journeys (pp. 36-48). London: Routledge.

Di Giovine, M. A. (2011). Pilgrimage: Communitas and contestation, unity and difference. An introduction. Tourism: An International and Interdisciplinary Journal, 59(3), 247-269.

El Hanandeh, A. (2013). Quantifying the Carbon Footprint of Religious Tourism: The Case of Hajj. Journal of Cleaner Production, 1(8).

Finn, J. (2009). Contesting culture: a case study of commercialization in Cuban music. GeoJournal, 74(3), 191-200.

Glaser, B. G., \& Strauss, A. L. (1967).The discovery of grounded theory :Strategies for qualitative research. New York: Aldine Pub. Co.

Go, F. (1997). Entrepreneurs and the tourism industry in developing countries. In H. Dahles (ed.) Tourism, small entrepreneurs and sustainable development, pp. 5-22, Tilburg: Atlas.

Goulding, C. (2000). The commercialization of the past, postmodern pastiche, and the search for authentic experiences at contemporary heritage attractions. European journal of marketing, 34(7), 835-853.

General Office of Henan Province. (1985). Henan Year Book. Zhengzhou, China: Henan Year Book Publish.

General Office of Henan Province. (1987). Henan Year Book. Zhengzhou, China: Henan Year Book Publish.

General Office of Henan Province. (2015). Henan Year Book. Zhengzhou, China: Henan Year Book Publish.

Hiller, H. L. (1976). Escapism, Penetration, and Responsec: Industrial Tourism and the Caribbean. Caribbean studies, 16(2), 92-116.

Hughes, K., Bond, N., \&Ballantyne, R. (2013). Designing and managing interpretive experiences at religious sites: Visitors' perceptions of Canterbury Cathedral. Tourism Management, 36, 210-220.

Jackson, R. H., \&Hudman, L. (1995). Pilgrimage tourism and English cathedrals: The role of religion in travel. Tourism Review, 50(4), 40-48.

Jirásek, I. (2011). Pilgrimage as a form of physical and movement spirituality.In J. Parry, M. 
Nesti, \&N. Watson (Eds.), Theology, ethics and transcendence in sports (pp. 223-232). Abingdon: Routledge.

Josan, I. (2009). Pilgrimage - A rudimentary form of modern tourism. GeoJournal of Tourism and Geocities, 2(2), 160-168.

Kamberelis, G.\&Dimitriadis, G. (2005). Focus Groups: Strategic articulations of Pedagogy, politics, and inquiry. In Denzin, N \& Lincoln, Y. (Ed.), The Sage Handbook of Qualitative Research, pp 887-908, California: Sage Publications.

Kang, X. (2009). Two temples, three religions, and a tourist attraction: Contesting sacred space on China's ethnic frontier. Modern China, 35(3), 227-255.

Kaszowski, L. (2000). Methodology of pilgrimage. Peregrinus Cracoviensis, 10, 75-82.

Kitzinger, J. \& Barbour, R. (1999). Introduction: the challenge and promise of focus groups. In Barbour, R., \&Kitzinger, J. (Ed.), Developing focus group research: Politics. Theory and Practice, pp 1-20, London: Sage Publications.

Kontogeorgopoulos, N., Churyen, A., \&Duangsaeng, V. (2015).Homestay Tourism and the Commercialization of the Rural Home in Thailand. Asia Pacific Journal of Tourism Research, 20(1), 29-50.

Langford, J. D., \&McDonagh, D. (2003).Focus Groups : Supporting Effective Product Development. London: Taylor \& Francis.

Levi, D., \& Kocher, S. (2009). Understanding tourism at heritage religious sites.Focus: Journal of The City and Regional Planning Department, 6(1), 6.

Lois-González, R. C., \& Santos, X. M. (2014).Tourists and pilgrims on their way to Santiago.Motives, Caminos and final destinations. Journal of Tourism and Cultural Change. (ahead-of-print), 1-16.

MacCannell, D. (1973). Staged authenticity: Arrangements of social space in tourist settings. American Journal of Sociology, 79(3), 589-603.

MacCannell, D. (1976). The tourist: A new theory of the leisure class. Univ of California Press.

Mason, K. (2004). Sound and meaning in aboriginal tourism. Annals of Tourism Research, 31(4), 837-854.

McKercher B \& du Cros H. (2002). Cultural Tourism: Partnership between Tourism and Cultural Heritage Management. Haworth Press: Binghamton, NY.

Morris, M. (2004). Transnational imagination in action cinema: Hong Kong and the making of a global popular culture. Inter-Asia Cultural Studies, 5 (2), 181-199.

Graburn, N. H. (1983). The anthropology of tourism. Annals of Tourism Research, 10(1), 9-33.

Nolan, M. L., \& Nolan, S. (1992). Religious sites as tourism attractions in Europe. Annals of Tourism Research, 19(1), 68-78.

Oakes, T. S. (1993). The cultural space of modernity: ethnic tourism and place identity in China. Environment and Planning D, 11, 47-47.

Olsen, D. H. (2003).Heritage, tourism, and the commercialization of religion. Tourism Recreation Research, 28(3), 99-104.

Olsen, D. H. (2006). Management issues for religious heritage attractions. Tourism, religion and spiritual journeys, 104-18. 
Olsen, D. H. (2013).A Scalar Comparison of Motivations and Expectations of Experience within the Religious Tourism Market. International Journal of Religious Tourism and

Pilgrimage, 1(1), 5.

Olsen, D. H., \& Timothy, D. J. (2002). Contested religious heritage: differing views of Mormon heritage. Tourism Recreation Research, 27(2), 7-15.

Özkan, C. (2013).The convergence or divergence of pilgrimage and tourism in modern China. International Journal of Social Inquiry, 6(2), 118-138.

Pavicic, J., Alfirevic, N., \&Batarelo, V. J. (2007). The management and marketing of religious sites, pilgrimages and religious events: Challenges for roman catholic pilgrimages in Croatia. In N. D.

Peelen, J., \& Jansen, W. (2007).Emotive movement on the road to Santiago de Compostela. Etnofoor, 75-96.

Philp, J., \& Mercer, D. (1999).Commercialization of Buddhism in contemporary Burma. Annals of Tourism Research, 26(1), 21-54.

Prahalad, C. K., \& Hamel, G. (1990). The Core Competence of the Corporation. Harvard Business Review, 68(3), 79-91.

Raj, R., \&Morpeth, N. D. (2007). Religious tourism and pilgrimage festivals management: An international perspective. CABI.

Reader, I. (2007). Pilgrimage growth in the modern world: Meanings and implications. Religion, 37, 210-229.

Rinschede, G. (1992). Forms of religious tourism. Annals of Tourism Research, 19(1), 51-67.

Roesch, S. (2009).The experiences of film location tourists (Vol. 42). Channel View Books.

Shackley, M. (2001). Managing sacred sites: Service provision and visitor experience. Cengage Learning Emea.

Shackley, M. (2002).Space, sanctity and service; the English Cathedral as heterotopia. International Journal of Tourism Research, 4(5), 345-352.

Shackley, M. (2003). Management challenges for religion-based attractions. Managing Visitor Attractions, 159-70.

Shackley, M. (2005). Service Delivery at Sacred Sites: Potential Contribution of Management Science. European Journal of Science and Theology, 1(4), 33-40.

Shahar, M. (2008).The Shaolin monastery: history, religion, and the Chinese martial arts. Honolulu: University of Hawaii Press.

Shinde, K. N. (2007). Pilgrimage and the environment: Challenges in a pilgrimage centre. Current Issues in Tourism, 10(4), 343-365.

Shoval, N. (2000). Commercialization and theming of the sacred: Changing patterns of tourist consumption in the 'Holy Land'. New forms of consumption: Consumers, culture and commercialization, 251-263.

Singh, R. P. (1997). Sacred space and pilgrimage in Hindu society: the case of Varanasi. Sacred places, Sacred spaces: The geography of pilgrimages, 34, 191-207.

Smith, V. L. (1992). The quest in guest. Annals of Tourism Research, 19(1), 1-17.

Smith, C., \& Jenner, P. (2000).Health tourism in Europe. Travel \& Tourism Analyst, (1), 41-59.

Stake, R. (2005) Qualitative case studies? In: N. K. Denzin, Y. S. Lincoln (eds), The Sage Handbook of Qualitative Research (3rd edn). London; Sage. 
Stausberg, M. (2011). Religion and tourism: Crossroads, destinations and encounters. London: Routledge.

Strauss, A. (1987). Qualitative analysis for social scientists. Cambridge: Cambridge University Press.

Su, X. (2011).Commercialization and the selling of ethnic music to tourists. Geoforum, 42(4), 496-505.

Swain, M. (1989).Developing ethnic tourism in Yunnan, China: Shilin Sani. Tourism Recreation Research, 14(1), 33-39.

Taylor, J. P. (2001). Authenticity and sincerity in tourism. Annals of Tourism Research, 28(1), 726.

The Shaolin Monastery (2010). Retrieved on March 10, 2010, from the World Wide Web, http://www.shaolin.org.cn/index.aspx

Timothy, D. J., \& Boyd, S. W. (2003). Heritage tourism. Pearson Education.

Timothy, D., \& Olsen, D. (Eds.).(2006). Tourism, religion and spiritual journeys (Vol. 4). Routledge.

Vukonic, B. (1996). Tourism and religion. Oxford: Pergamon.

Wang, N. (1999). Rethinking authenticity in tourism experience. Annals of Tourism Research, 26(2), 349-370.

Wang, N. (2007). Interactive authenticity in tourism -- A case study on hospitality tourism. Journal of Guangxi University for Nationalities, 29(6), 18-24.

Wang, N. (2014). Differences of cultural psychology in tourism ethics and authenticity experience. Tourism Tribune, 29(11), 5-6.

Waitt, G. (2000). Consuming heritage: Perceived historical authenticity. Annals of Tourism Research, 27(4), 835-862.

Winter, M., \&Gasson, R. (1996). Pilgrimage and tourism: cathedral visiting in contemporary England. International Journal of Heritage Studies, 2(3), 172-182.

Xie, P. F. (2003). The bamboo-beating dance in Hainan, China: Authenticity and commercialization. Journal of Sustainable Tourism, 11(1), 5-16.

Xu, K. S., Yan, T., \& Zhu, X. (2013).Commercialization of Chinese heritage villages. Annals of Tourism Research, 40(1), 415-419.

Zhu, Y. (2012). Performing heritage: Rethinking authenticity in tourism. Annals of Tourism Research, 39(3), 1495-1513. 